\title{
RESEARCH
}

Open Access

\section{Stability indicating method development and validation for simultaneous estimation and quantification of Ertugliflozin and Metformin in bulk and tablet dosage form}

\author{
Bhawani Sunkara ${ }^{1 *}$ (D), Tulja Rani Gampa ${ }^{1,2}$, Mounika Markanti ${ }^{1}$ and Ratna Kumari Midthapally ${ }^{1}$
}

\begin{abstract}
Background: A simple, economical, sensitive, authentic, and faithful technique was used for the study of simultaneous evaluation of Ertugliflozin and Metformin in tablet dosage forms. The Chromatographic analysis was performed isocratically by using a Phenomenex C18 column (150 mm $\times 4.6 \mathrm{~mm}, 5 \mu \mathrm{m})$, and a mobile phase containing acetonitrile and $0.1 \%$ OPA buffer, with a proportion of 40: $60 \% \mathrm{v} / \mathrm{V}$ was passed throughout the column maintained at a temperature of $30{ }^{\circ} \mathrm{C}$ with a flow rate of $1 \mathrm{ml} / \mathrm{min}$. Approximately, $10 \mu \mathrm{l}$ of drug solution was injected and the analytes were eluted at $220.0 \mathrm{~nm}$.

Results: The elution times of Ertugliflozin and Metformin were 2.226 min and 2.955 min, respectively. The percentage RSD of Ertugliflozin and Metformin are 0.60 and 0.59 , respectively. The percentage recoveries of Ertugliflozin and Metformin were determined to be $100.55 \%$ and $99.40 \%$, respectively. LOD, LOQ values of Metformin and Ertugliflozin obtained were found to be $0.10,0.2 \mu \mathrm{g} / \mathrm{ml}$ and $0.03,0.09 \mu \mathrm{g} / \mathrm{ml}$, respectively. Regression equation of Ertugliflozin was $y=11287 x+1191$ and $y=46270 x+161.0$ for Metformin. All verification parameters are within the range according to the $\mathrm{ICH}$ guidelines, and the degradation products are also within the limits, which show that the method is stable.

Conclusion: In the currently developed RP-HPLC analytical method, the elution time and run time is reduced, which proves that the method is economical and widely acceptable, also simple and practical, which can be used in routine quality control tests in the industry.
\end{abstract}

Keywords: Ertugliflozin, Metformin, Retention time, Retention time, Forced degradation studies, Resolution

\footnotetext{
* Correspondence: banu.sunkara@gmail.com

${ }^{1}$ Malla Reddy Institute of Pharmaceutical Sciences, Hyderabad, Telangana,

India

Full list of author information is available at the end of the article
}

(ㅇ The Author(s). 2021 Open Access This article is licensed under a Creative Commons Attribution 4.0 International License, which permits use, sharing, adaptation, distribution and reproduction in any medium or format, as long as you give appropriate credit to the original author(s) and the source, provide a link to the Creative Commons licence, and indicate if changes were made. The images or other third party material in this article are included in the article's Creative Commons licence, unless indicated otherwise in a credit line to the material. If material is not included in the article's Creative Commons licence and your intended use is not permitted by statutory regulation or exceeds the permitted use, you will need to obtain permission directly from the copyright holder. To view a copy of this licence, visit http://creativecommons.org/licenses/by/4.0/. 


\section{Background}

Ertugliflozin has a place with the class of strong and particular inhibitors of the sodium-subordinate glucose cotransporters (SGLT) [1]; all the more explicitly the sort 2 which is liable for about $90 \%$ of the glucose reabsorption from glomerulus [2, 3]. It became FDA endorsed as monotherapy and in combination with sitagliptin or metformin hydrochloride on 22 December 2017.

In grown up patients enduring with type 2 diabetes, Ertugliflozin as a monotherapy has been seemed to reinforce the glycemic regulation. Ertugliflozin, in combination with metformin hydrochloride, is demonstrated to enhance glycemic control in sufferers with diabetes type 2 who are not controlled on a recurring of Ertugliflozin or metformin or in patients who are now dealt with both

\section{Metformin}

Metformin has a place with the classification biguanides oral anti-diabetes drug [4]. This is the primary essential drug for the determination of type 2 diabetes, particularly in overweight and hefty people and those with typical kidney function. Its utilization in gestational diabetes has been constrained by security concerns despite the fact that in any event one examination has been directed which indicated no worries for youngsters prenatally presented to Metformin as long as 2 years old. It is additionally utilized in the treatment of polycystic ovary disorder and has been explored for different ailments where insulin obstruction might be a significant factor. Metformin works by suppressing glucose creation from three-carbon particles (like propionic acid), a result of dietary fiber aging in the large intestine and pyruvate, a by-product of glucose breakdown in the muscles by the liver [5-7]. FDA approved a set combination of Ertugliflozin and Metformin for the regulation of blood glucose levels in patients with type II diabetes [8-10]. Structures of Ertugliflozin and Metformin were given as Figs. 1 and 2.

\section{Methods}

Ertugliflozin and Metformin were procured as gift samples from Startech laboratories.

Segluromet formulation combination of Metformin and Ertugliflozin was obtained from local pharmacy store.

Acetonitrile, Methanol of HPLC grade, and O-phosphoric acid of analytical grade were obtained from Rankem laboratories.

\section{Chromatographic conditions \\ Equipment}

Waters HPLC 2695 chromatographic System set with quaternary pumps, Photo Diode Array detector and Auto sampler. Chromatograms were recorded using Empower 2 Software.

\section{Chromatographic conditions}

Mobile phase: 0.1\%OPA buffer: Acetonitrile (60:40\% v/v)

Column: Phenomenex $(4.6 \mathrm{~mm} \times 150 \mathrm{~mm}, 5 \mu \mathrm{m})$

Flow rate: $1.0 \mathrm{ml} \mathrm{min}^{-1}$

Column temperature: $30{ }^{\circ} \mathrm{C}$

Programming: Isocratic

Wavelength: $220 \mathrm{~nm}$

Run time: $10 \mathrm{~min}$

Sample volume: $10 \mu \mathrm{l}$

\section{Solvent}

Acetonitrile $(\mathrm{ACN})$ and water in the ratio $50: 50 \% \mathrm{v} / \mathrm{v}$ is used as solvent.

Both standard and sample solutions were filtered through $0.45 \mu \mathrm{m}$ before injecting into the HPLC.

\section{Preparation of standard solutions}

Standard stock solution of $15 \mu \mathrm{g} \mathrm{m}{ }^{-1}$ of Ertugliflozin and $1000 \mu \mathrm{g} \mathrm{ml}^{-1}$ of metformin were prepared by weighing accurately $0.75 \mathrm{mg}$ of Ertugliflozin and $50 \mathrm{mg}$ of Metformin and transferring to $50 \mathrm{ml}$ volumetric flask. Three-fourth volume of diluent was added and kept for sonication for $25 \mathrm{~min}$ and finally they were made up to

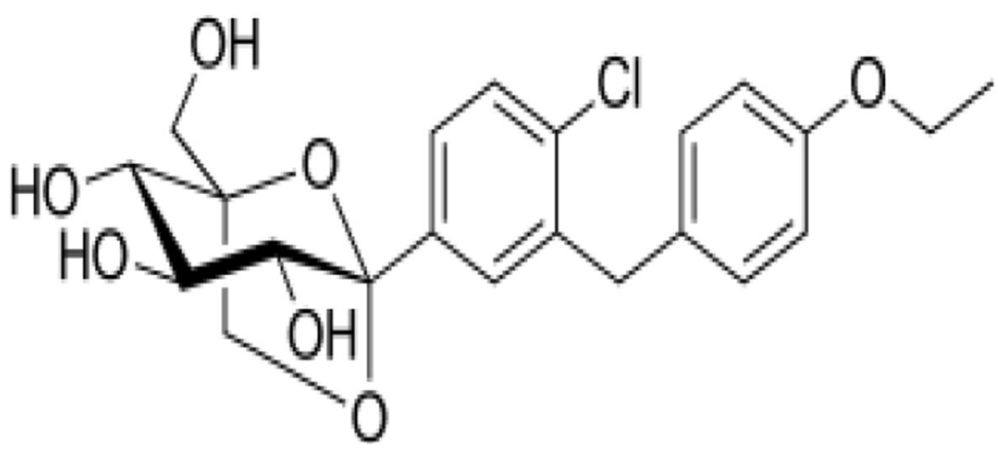

Fig. 1 Structure of Ertugliflozin 


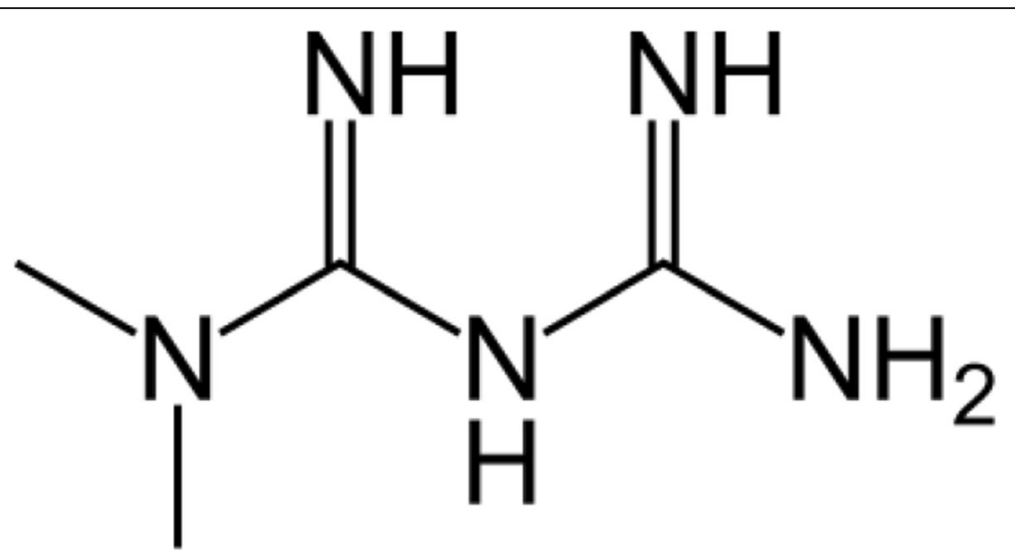

Fig. 2 Structure of metformin

the mark using the diluent. Working standard solution of conc $100 \mu \mathrm{g} / \mathrm{ml}$ of Metformin and $1.5 \mu \mathrm{g} / \mathrm{ml}$ of Ertugliflozin was obtained by pipetting out $1 \mathrm{ml}$ of stock solution and transferring it to $10 \mathrm{ml}$ volumetric flask and making up to the mark with the diluent.

\section{Preparation of sample solutions}

Weigh 20 tablets, calculate the average weight. Weight equivalent to one tablet was transferred to volumetric flask of $500 \mathrm{ml}$, next $50 \mathrm{ml}$ of diluent was applied and sonicated for $25 \mathrm{~min}$, further volume was made up to the mark using diluent to obtain concentration of 1000 $\mu \mathrm{g} / \mathrm{ml}$ of metformin and $15 \mu \mathrm{g} / \mathrm{ml}$ of Ertugliflozin. Then, $1 \mathrm{ml}$ of filtered sample stock solution was transferred to $10 \mathrm{ml}$ volumetric flask and made up with diluent to obtain concentration of $100 \mu \mathrm{g} / \mathrm{ml}$ of Metformin and 1.5 $\mu \mathrm{g} / \mathrm{ml}$ of Ertugliflozin.

\section{Buffer}

0.1\%OPA buffer: $0.1 \mathrm{ml}$ orthophosphoric acid diluted to $100 \mathrm{ml}$ using water of HPLC grade.

\section{Validation}

\section{System suitability}

System suitability parameters were evaluated and analyzed to check system performance using standard solutions of Ertugliflozin (1.5 ppm) and Metformin (100 ppm).

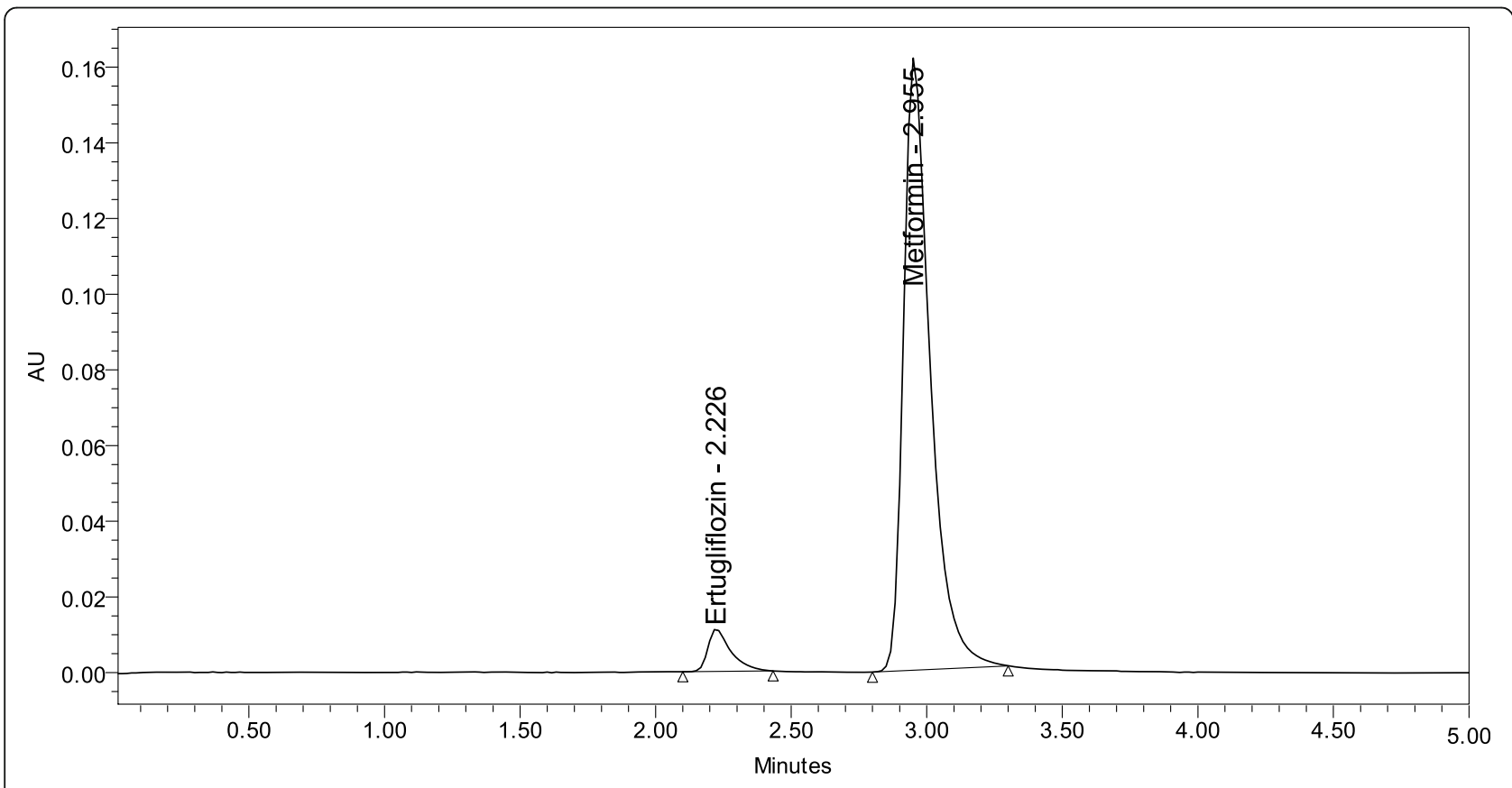

Fig. 3 Optimized chromatogram 


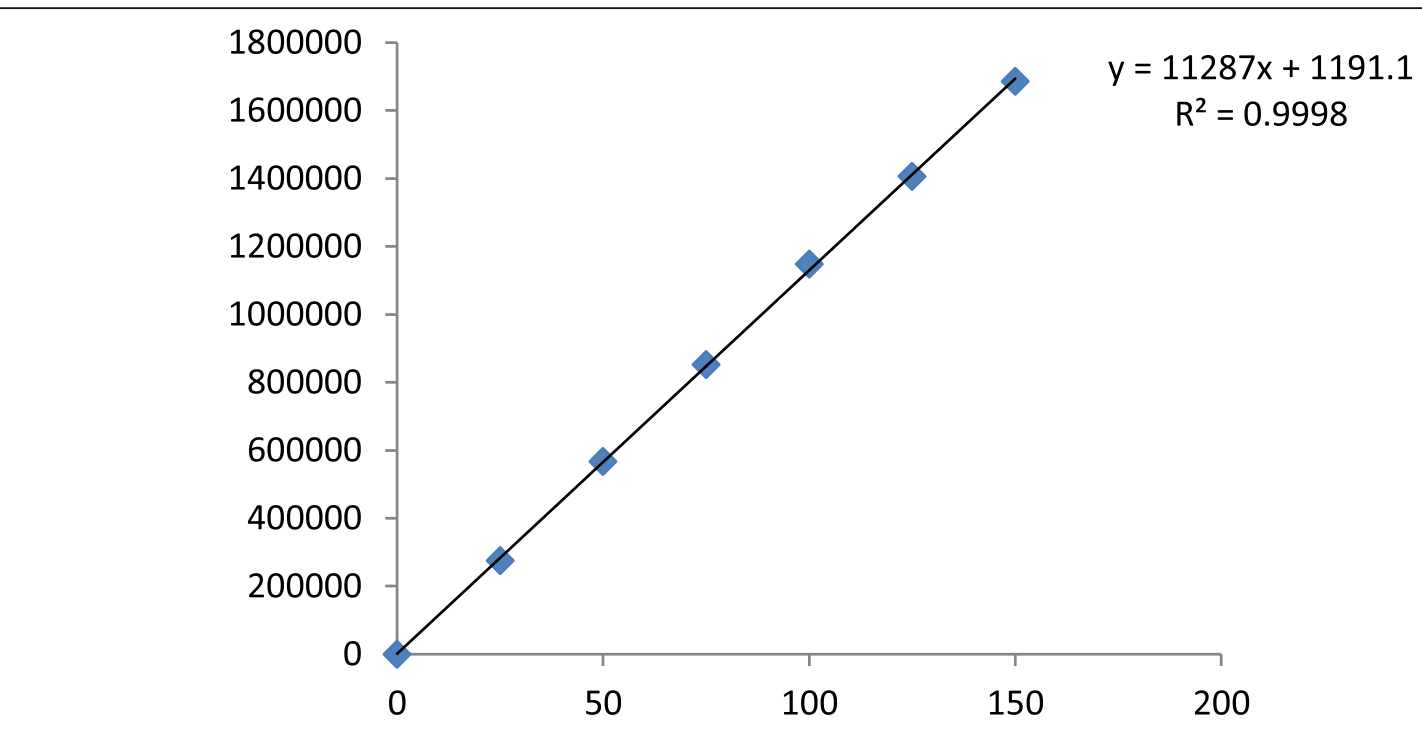

Fig. 4 Linearity of Metformin

\section{Linearity}

Linearity is to produce test results that are exactly proportional to the analyte concentration in the sample. It is obtained with in the concentration range of $0.375-2.25 \mu \mathrm{g} / \mathrm{ml}$ for Ertugliflozin and 25-150 $\mu \mathrm{g} /$ $\mathrm{ml}$ for metformin. The calibration graph is plotted with $X$-axis concentration and $Y$-axis peak areas and seen in Figs. 3 and 4.

\section{Specificity}

The interference in the optimized method is verified. There is no evidence of interference of peaks in blank and placebo at retention times of these drugs in this method. So, the developed method is specific.

\section{Accuracy}

Accuracy is a measure of how close is the experimental value to the true value. Accuracy is determined by calculating the recovery values accuracy is done at intervals of $50 \%, 100 \%$, and $150 \%$ levels. \% recovery and \% RSD were taken into consideration.

\section{Precision}

Precision is defined as the closeness of agreement between a series of measurements obtained from multiple sampling of the homogeneous sample. It is estimated by injecting six replicates of Ertugliflozin of conc $1.5 \mathrm{ppm}$ and metformin of conc $100 \mathrm{ppm}$.

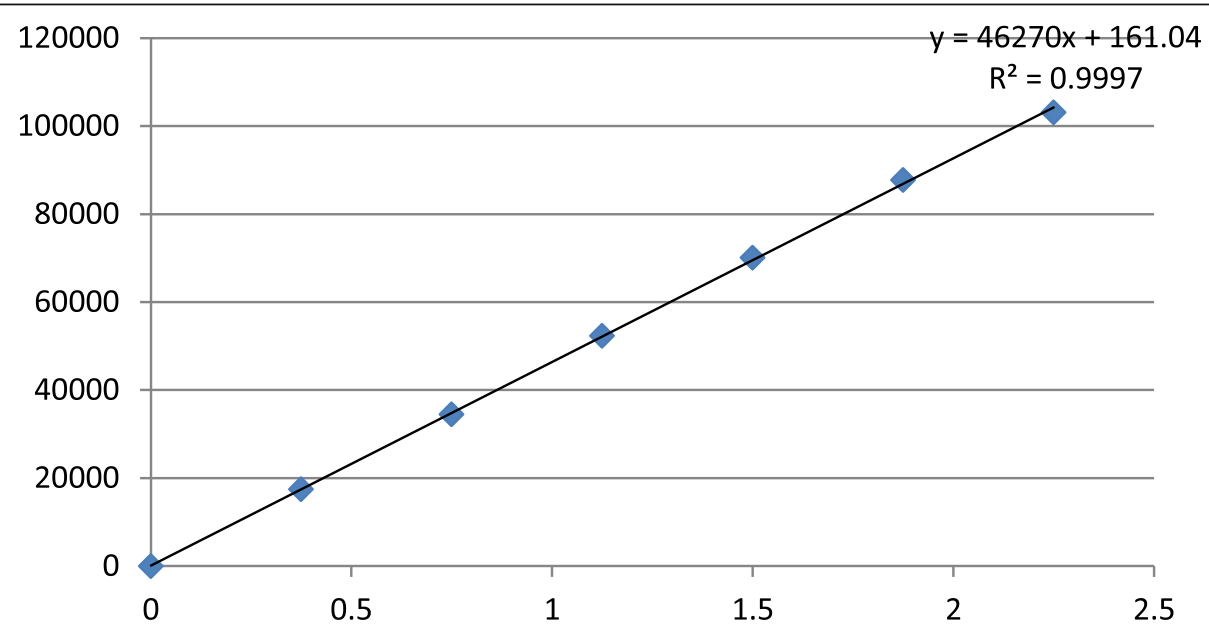

Fig. 5 Linearity of Ertugliflozin 


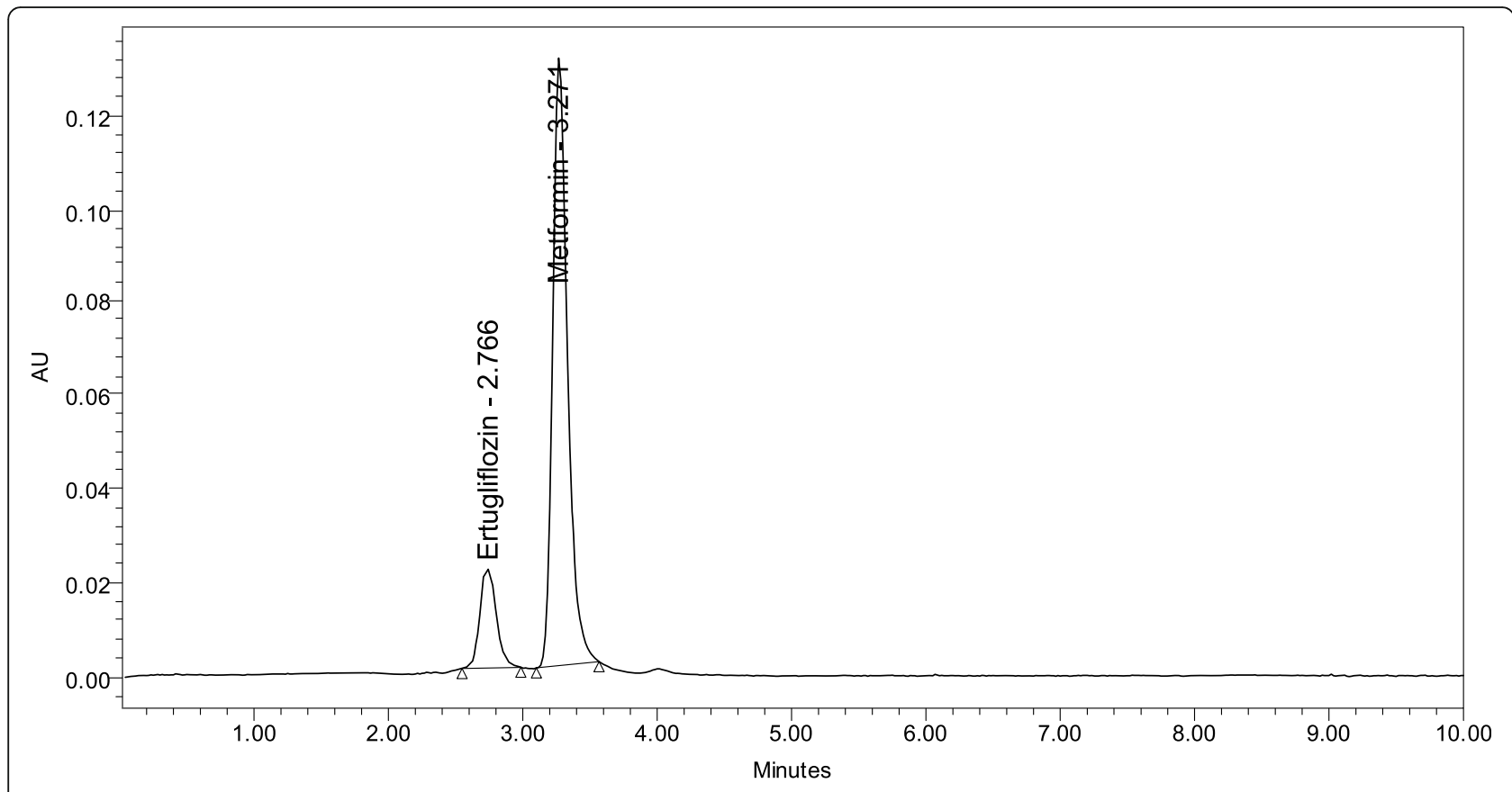

Fig. 6 Acid degradation chromatogram of Ertugliflozin and Metformin

\section{$\angle O D$ and $L O Q$}

Limit of detection (LOD) and limit of quantification (LOQ) of Ertugliflozin and Metformin were determined from the calibration curve method using the following equations:

$$
\begin{aligned}
& \mathrm{LOD}=3.3 \times \alpha / \mathrm{s} \\
& \mathrm{LOQ}=10 \times \alpha / \mathrm{s}
\end{aligned}
$$

Where $\alpha$ is standard deviation, $s$ is the slope.

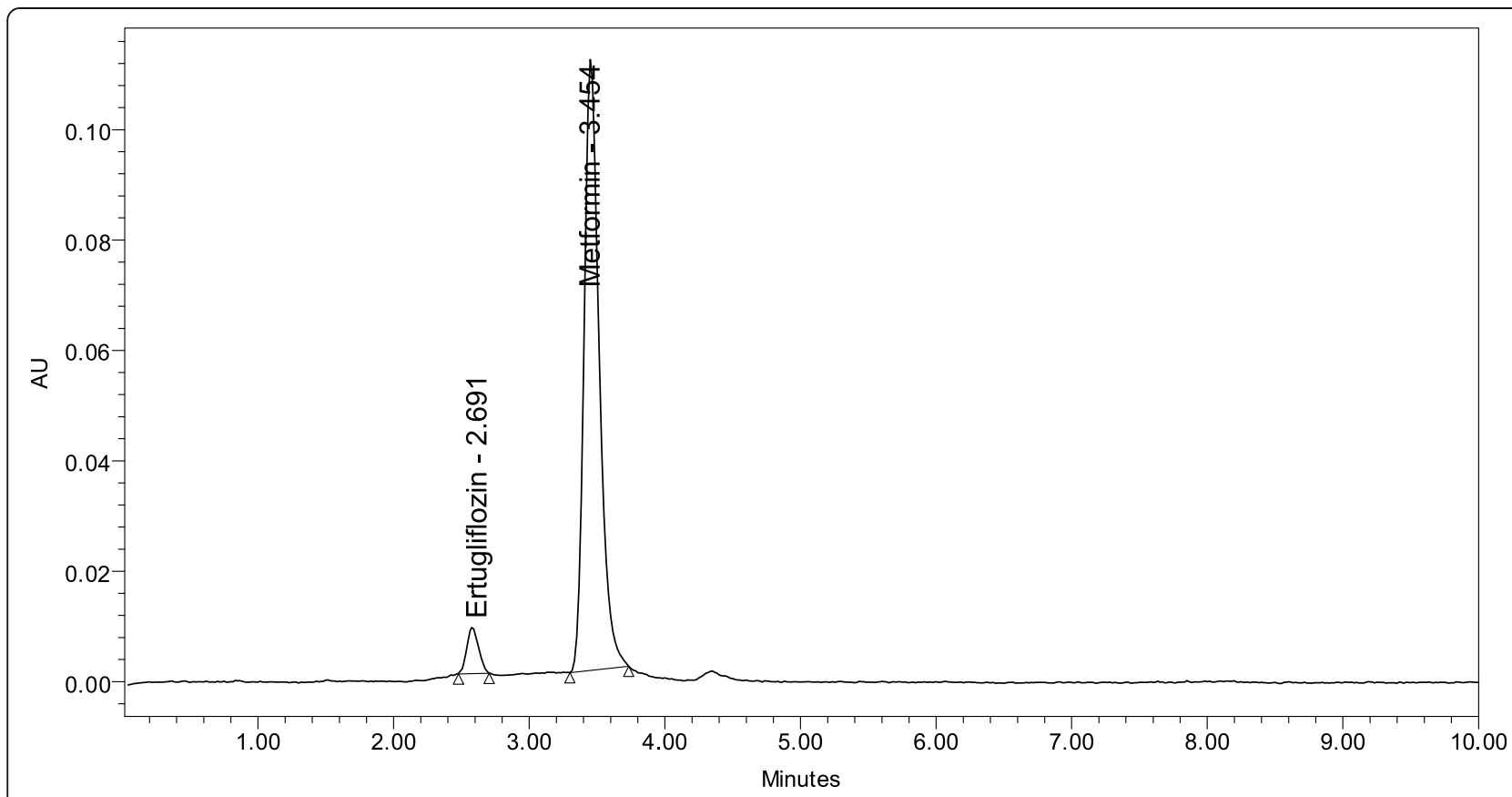

Fig. 7 Base degradation chromatogram of Ertugliflozin and Metformin 


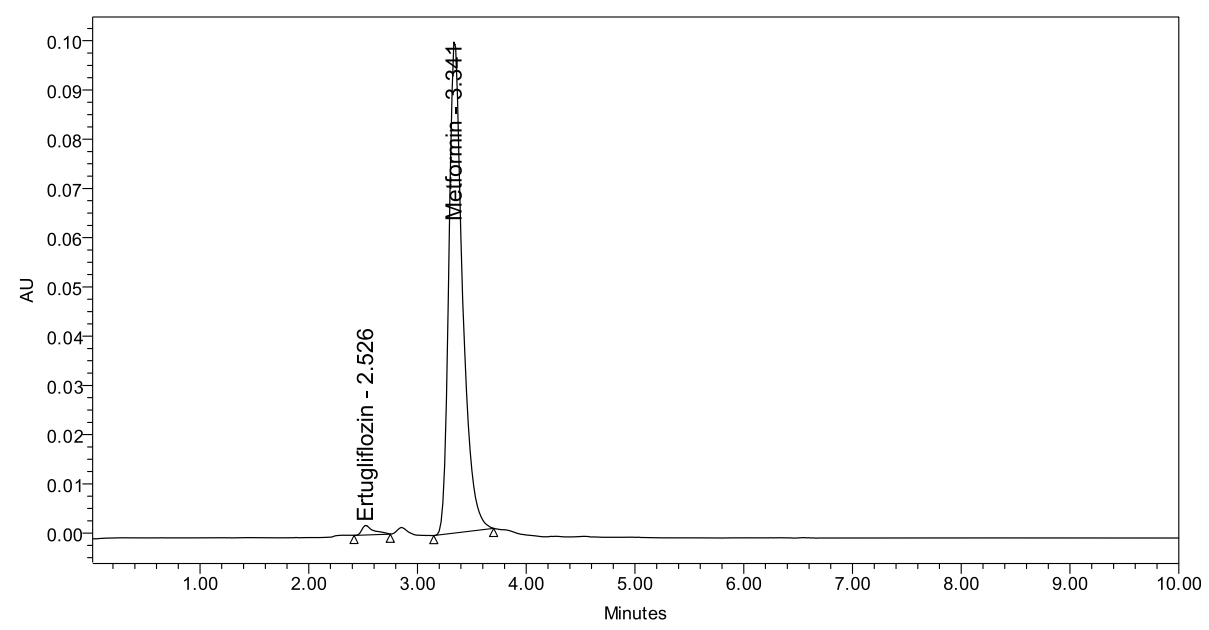

Fig. 8 Chromatogram of Ertugliflozin and Metformin subjected to peroxide degradation

\section{Robustness}

Even though there are small deliberate changes in method like flow rate, mobile phase ratio, and temperature there is no change in the result and the results are within range as per ICH Guide lines.

\section{Assay}

Segluromet bearing the label claim Metformin $500 \mathrm{mg}$ and Ertugliflozin $7.5 \mathrm{mg}$. Assay was performed with the above formulation. Average \% Assay for Metformin and Ertugliflozin obtained was found to be 101.32 and $99.46 \%$, respectively.

\section{Forced degradation studies}

This was achieved by following recommendations of an international conference on harmonization [11-13].
Standard samples of Ertugliflozin and Metformin were degraded under different stress conditions like acidic, alkali, oxidative, thermal, photostability, and neutral conditions.

Samples for acidic and alkali degradation were refluxed at $60{ }^{\circ} \mathrm{C}$ for $30 \mathrm{~min}$ with $2 \mathrm{~N} \mathrm{HCl}$ and $2 \mathrm{~N} \mathrm{NaOH}$. Oxidative degradation is carried out by using $20 \% \mathrm{H} 2 \mathrm{O} 2$ and kept aside for $30 \mathrm{~min}$ at $60{ }^{\circ} \mathrm{C}$. Thermal degradation is done by placing the sample in an oven at $105^{\circ} \mathrm{C}$ for $6 \mathrm{~h}$. For photostability, studies the sample solutions were subjected to UV light by placing the sample in photo stability chamber for 7 days or $200 \mathrm{~W} \mathrm{~h} / \mathrm{m}^{2}$. The sample solutions were refluxed in water for $6 \mathrm{~h}$ at $60{ }^{\circ} \mathrm{C}$.All the samples were finally diluted to obtain concentration of $1.5 \mu \mathrm{g} / \mathrm{ml}$ of Ertugliflozin and $100 \mu \mathrm{g} / \mathrm{ml}$ of Metformin. Ten microliters was injected into the system and the chromatogram is recorded to assess the stability of sample. Chromatograms of acid, alkali,peroxide,thermal,U.V and water stress conditions were depicted as Figs. 5, 6, 7, 8, 9 and 10

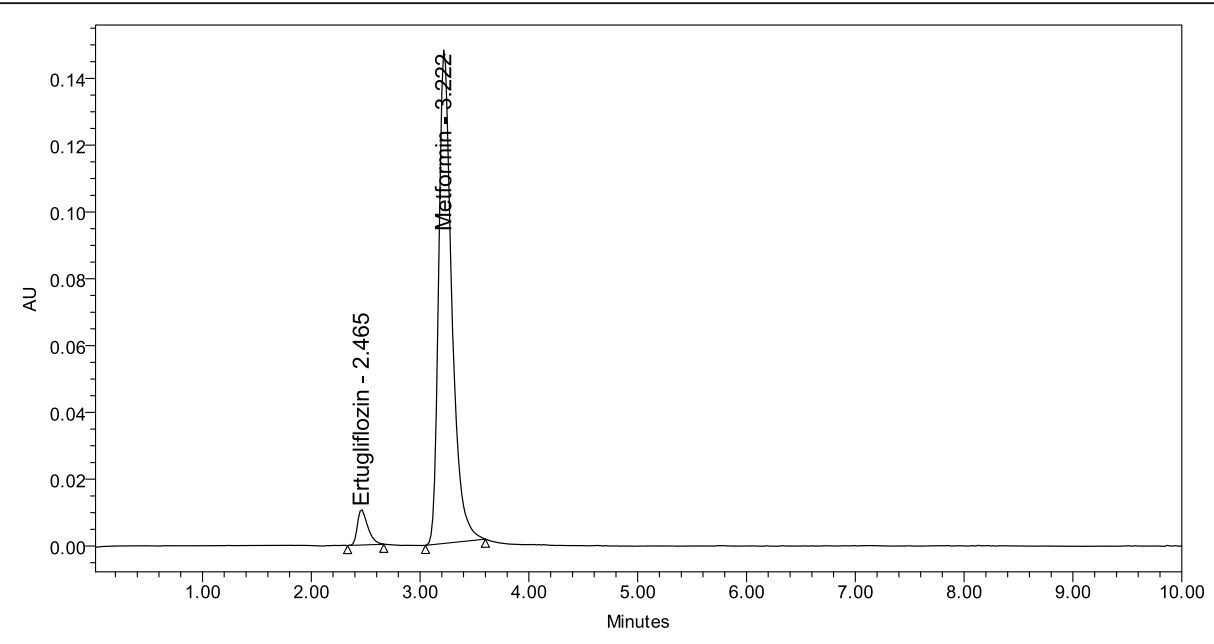

Fig. 9 Thermal degradation chromatogram of Ertugliflozin and Metformin 


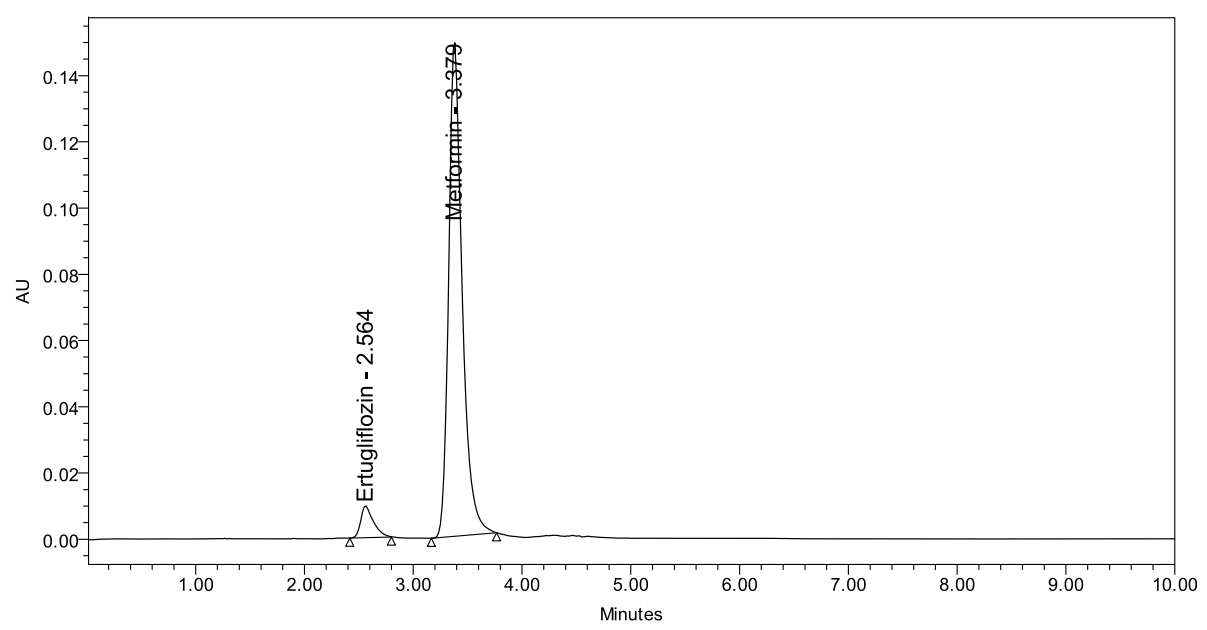

Fig. 10 UV chromatogram of Ertugliflozin and Metformin

\section{Results}

\section{Optimized method}

Strategy streamlining has done by actualizing experimentation technique in such a manner to get a chromatogram with good resolution(R), proficiency, acknowledged number of theoretical plates, and tailing factor. In this strategy, a few preliminaries have been finished by changing organic phase proportion and flow rate. At last, the strategy with Phenomenex $150(4.6 \times 150 \mathrm{~mm}, 5 \mu \mathrm{m})$, mobile phase composition of $0.1 \% \mathrm{OPA}$ buffer: Acetonitrile $(60: 40 \mathrm{v} / \mathrm{v})$ and a flow rate of $1 \mathrm{~mL} / \mathrm{min}$ was chosen as advanced technique. Various trails were carried out using different compositions of mobile phase and different columns based on the literature review [14-18] and optimized chromatogram was shown in Fig. 11.

\section{Validation}

Validation is done in accordance with the guidelines framed by the ICH [19].

\section{System suitability}

All the system suitability parameters like tailing factor should be less than 2, theoretical plates greater than 2000, resolution more than 2, \% RSD of peak areas less than 2 were evaluated to show that the values were reproducible. In the current method, all the parameters were established within limits which prove that the values are reproducible and the results were summarized in (Table 1).

\section{Linearity}

Linearity was determined over the range of (25-150 $\mu \mathrm{g} / \mathrm{ml})$ for Metformin and $(0.375-2.25 \mu \mathrm{g} / \mathrm{ml})$ for

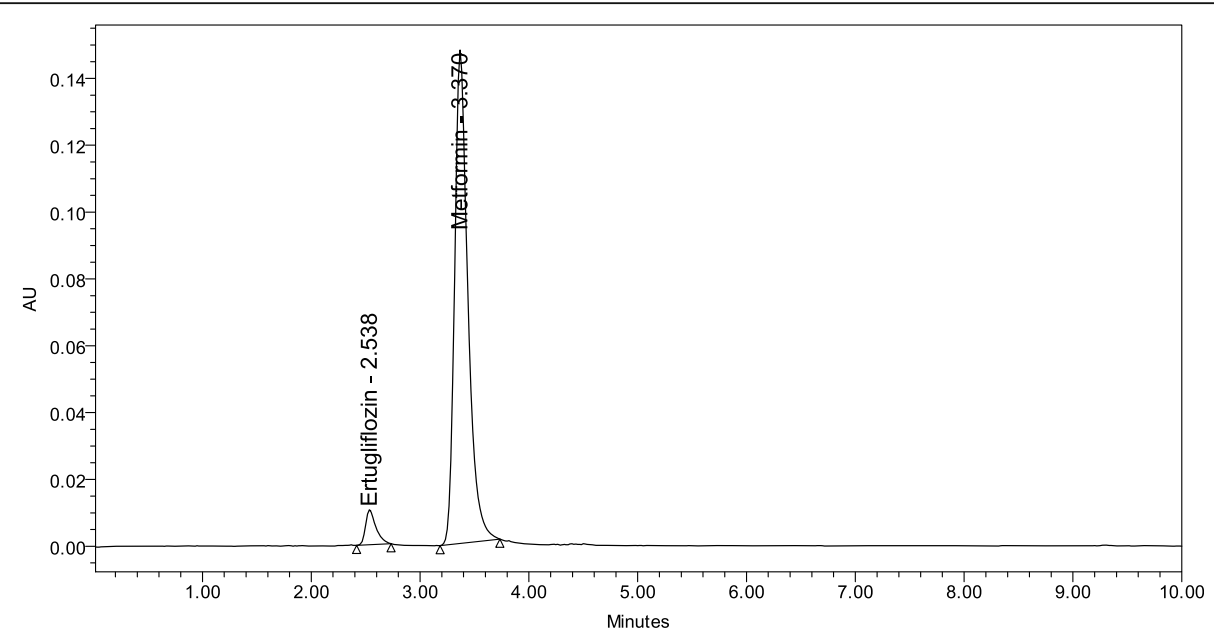

Fig. 11 Water chromatogram of Ertugliflozin and Metformin 
Table 1 System suitability parameters for Metformin and Ertugliflozin

\begin{tabular}{llll}
\hline Sr.no & Parameter & Ertugliflozin & Metformin \\
\hline 1 & Retention time & 2.226 & 2.955 \\
2 & Theoretical plates & 3424 & 4098 \\
3 & Tailing factor & 1.6 & 1.48 \\
4 & Peak area & 69546 & 1117544 \\
5 & \% RSD & 0.6 & 0.59 \\
6 & Resolution & 4.2 & \\
\hline
\end{tabular}

Ertugliflozin. Regression equation obtained for Metformin was $y=11287 x+1191$ and for Ertugliflozin it was $y=46270 x+16$.

\section{Precision}

\section{System precision}

Percentage RSD values for both intra and inter day precision were within the range that is less than 2 . The results were summarized in the (Table 2).

\section{Accuracy}

Accuracy results at various levels of concentration were summarized in the (Table 3).

\section{Sensitivity}

The present method can detect and quantify the analyte at lower concentration (Table 4).

LOD and LOQ values were calculated using the formulae

$$
\mathrm{LOD}=3.3 \times \alpha / \mathrm{s} \quad \mathrm{LOQ}=10 \times \alpha / \mathrm{s}
$$

Where $\alpha$ is the standard deviation of the response of regression lines and $s$ is the slope obtained from the calibration curve.

Table 2 Precision results of Metformin and Ertugliflozin

\begin{tabular}{lll}
\hline Sr. no & Peak area of Metformin & Peak area of Ertugliflozin \\
\hline 1. & 1121207 & 69463 \\
2. & 1121759 & 70550 \\
3. & 1136020 & 70070 \\
4. & 1117544 & 69546 \\
5. & 1119237 & 70283 \\
6. & 1125636 & 69913 \\
Mean & 1123567 & 69971 \\
S.D & 6681.6 & 420.6 \\
\%RSD & 0.59 & 0.6 \\
\hline
\end{tabular}

Table 3 Recovery results of Metformin and Ertugliflozin

\begin{tabular}{|c|c|c|c|c|c|c|}
\hline \multicolumn{3}{|c|}{ Metformin } & \multicolumn{4}{|c|}{ Ertugliflozin } \\
\hline $\begin{array}{l}\% \\
\text { Level }\end{array}$ & $\begin{array}{l}\text { Amount } \\
\text { added } \\
(\mu \mathrm{g} / \mathrm{mL})\end{array}$ & $\begin{array}{l}\text { Amount } \\
\text { recovered } \\
(\mu \mathrm{g} / \mathrm{mL})\end{array}$ & $\begin{array}{l}\% \\
\text { Recovery }\end{array}$ & $\begin{array}{l}\text { Amount } \\
\text { added } \\
\text { ( } \mu \mathrm{g} / \mathrm{mL})\end{array}$ & $\begin{array}{l}\text { Amount } \\
\text { recovered } \\
(\mu \mathrm{g} / \mathrm{mL})\end{array}$ & $\begin{array}{l}\% \\
\text { Recovery }\end{array}$ \\
\hline \multirow[t]{3}{*}{$50 \%$} & 50 & 49.54 & 99.07 & 0.75 & 0.76 & 101.02 \\
\hline & 50 & 49.54 & 99.07 & 0.75 & 0.76 & 101.02 \\
\hline & 50 & 49.09 & 98.19 & 0.75 & 0.74 & 99.00 \\
\hline \multirow[t]{3}{*}{$100 \%$} & 100 & 100.46 & 100.46 & 1.50 & 1.51 & 100.87 \\
\hline & 100 & 98.95 & 98.95 & 1.50 & 1.52 & 101.50 \\
\hline & 100 & 100.29 & 100.29 & 1.50 & 1.52 & 101.50 \\
\hline \multirow[t]{3}{*}{$150 \%$} & 150 & 150.54 & 100.36 & 2.25 & 2.24 & 99.72 \\
\hline & 150 & 148.51 & 99.01 & 2.25 & 2.25 & 100.15 \\
\hline & 150 & 148.77 & 99.18 & 2.25 & 2.25 & 100.15 \\
\hline
\end{tabular}

\section{Robustness}

In view of the outcomes, the developed analytical method was proved to be robust (Table 5).

\section{Assay}

Average \% Assay for Metformin and Ertugliflozin obtained was found to be 101.32 and $99.46 \%$ correspondingly and the results were summarized in (Table 6).

\section{Degradation}

Degradation studies show that Metformin and Ertugliflozin were well separated from the degradation products that were formed in different stress conditions. As per the $\mathrm{ICH}$ guidelines, \% degradation should be less than $20 \%$ to consider the particular method as stable. In this method, \% degradation was found to be less than $10 \%$ which proves that the method was stable and specific. Thus, the developed analytical method is stable and able to separate both Metformin and Ertugliflozin even in the presence of degraded products. \% amount degraded is shown in (Table 7).

\section{Discussion}

The stability indicating [11-13] RP-HPLC technique assumes a vital role in assurance of stability, both subjective and quantitative estimation of API and formulation. Till date, numerous explanatory techniques [14-18] have been created for Ertugliflozin and Metformin individual and in blend with other anti-diabetic drugs. Subsequently, endeavors were

Table $4 \mathrm{LOD}$ and LOQ results of Metformin and Ertugliflozin

\begin{tabular}{lll}
\hline Drug & LOD & LOQ \\
\hline Metformin & $0.10 \mu \mathrm{g} / \mathrm{ml}$ & $0.03 \mu \mathrm{g} / \mathrm{ml}$ \\
Ertugliflozin & $0.2 \mu \mathrm{g} / \mathrm{ml}$ & $0.09 \mu \mathrm{g} / \mathrm{ml}$ \\
\hline
\end{tabular}


Table 5 Robustness method of Metformin and Ertugliflozin

\begin{tabular}{lllll}
\hline Sr. no & Varying conditions & $\begin{array}{l}\text { \%RSD of } \\
\text { Metformin } \\
\text { Metformin }\end{array}$ & $\begin{array}{l}\text { \%RSD of } \\
\text { Ertugliflozin }\end{array}$ \\
\hline 1 & Change in flow & $0.9 \mathrm{ml} \mathrm{min}$ m $^{-1}$ & 0.6 & 1.1 \\
& & $1.1 \mathrm{ml} \mathrm{min}$ min $^{-1}$ & 0.1 & 0.3 \\
2 & $\begin{array}{l}\text { Change in mobile } \\
\text { phase }\end{array}$ & $65 \mathrm{~B}: 35 \mathrm{~A}$ & 0.6 & 0.8 \\
& & $55 \mathrm{~B}: 45 \mathrm{~A}$ & 0.5 & 0.1 \\
& $\begin{array}{l}\text { Change in } \\
\text { temperature }\end{array}$ & $25^{\circ} \mathrm{C}$ & 0.5 & 0.5 \\
& & $35^{\circ} \mathrm{C}$ & 0.2 & 0.4 \\
\hline
\end{tabular}

made to build up a successful soundness demonstrating RP-HPLC strategy. Various parameters and variable effects on peak shape, RT, and resolution were studied well. Column was also opted in such a way that which gave the best result. Analytes were eluted before $5 \mathrm{~min}$, RT in the existing technique was 2.226 min for Ertugliflozin and $2.955 \mathrm{~min}$ for Metformin, speaks to the strategy with great and successful maintenance time and can be treated as practical as it lessens solvent utilization and analyte run time which proves it is economical and simple. Correlation coefficient of the developed method was very close to 1.0, which supports the sensitivity of the method. Intra and inter day analysis was also performed which proves that the developed method was precise. Validity of the developed method was proved by investigating and evaluating the parameters like linearity, accuracy, precision, sensitivity, and repeatability. Forced degradation studies were also carried out by exposing the drugs to acidic, alkaline, thermal, oxidative, photolytic, and neutral conditions to indicate the stability of the current method. The currently developed method is able to separate the

Table 6 Results of Assay of Metformin and Ertugliflozin

\begin{tabular}{|c|c|c|c|c|c|c|}
\hline \multicolumn{4}{|c|}{ Metformin } & \multicolumn{3}{|c|}{ Ertugliflozin } \\
\hline Sr. no & $\begin{array}{l}\text { Standard } \\
\text { peak area }\end{array}$ & $\begin{array}{l}\text { Sample } \\
\text { peak } \\
\text { area }\end{array}$ & $\begin{array}{l}\% \\
\text { Assay }\end{array}$ & $\begin{array}{l}\text { Standard } \\
\text { peak area }\end{array}$ & $\begin{array}{l}\text { Sample } \\
\text { peak area }\end{array}$ & $\begin{array}{l}\% \\
\text { Assay }\end{array}$ \\
\hline 1 & 1121207 & 1109723 & 98.67 & 69463 & 69957 & 99.88 \\
\hline 2 & 1121759 & 1119654 & 99.55 & 70550 & 69551 & 99.30 \\
\hline 3 & 1136020 & 1114912 & 99.13 & 70070 & 70503 & 100.66 \\
\hline 4 & 1117544 & 1121838 & 99.75 & 69546 & 69822 & 99.69 \\
\hline 5 & 1119237 & 1119286 & 99.52 & 70283 & 70100 & 100.08 \\
\hline 6 & 1125636 & 1131060 & 100.57 & 69913 & 69438 & 99.14 \\
\hline Avg & 1123567 & 1119412 & 99.53 & 69971 & 69895 & 99.79 \\
\hline St. dev & 6681.6 & 7152.1 & 0.64 & 420.6 & 386.8 & 0.55 \\
\hline \%RSD & 0.59 & 0.63 & 0.64 & 0.6 & 0.55 & 0.55 \\
\hline
\end{tabular}

Table 7 Results of forced degradation study of Metformin and Ertugliflozin

\begin{tabular}{llll}
\hline S. no. & $\begin{array}{l}\text { Stress degradation } \\
\text { condition }\end{array}$ & $\begin{array}{l}\text { \% Degraded } \\
\text { Metformin }\end{array}$ & $\begin{array}{l}\text { \% Degraded } \\
\text { Ertugliflozin }\end{array}$ \\
\hline 1 & Acid & 6.54 & 3.45 \\
2 & Alkali & 8.39 & 3.94 \\
3 & Oxidation & 5.67 & 5.31 \\
4 & Thermal & 3.05 & 2.05 \\
5 & UV & 2.30 & 1.08 \\
6 & Water & 0.53 & 0.28 \\
\hline
\end{tabular}

active pharmaceutical ingredient from any degradants which proves that the method is stable. Consequently, fast examination of increasingly number examples is possible. The determined and measurable results of the approval parameters were not out of as far as possible expressed by $\mathrm{ICH}$.

\section{Conclusion}

Development of an accurate and efficient analytical method to determine and evaluate the quality of the drug substances are some of the critical activities carried out during process research and development to meet the requirements of different regulatory authorities. A simple, accurate, precise method was developed for the simultaneous estimation of the Ertugliflozin and Metformin in tablet dosage form. Forced degradation studies were finished by applying a few pressure conditions to evaluate the strength of the method. The proposed technique was effectively isolating both the drug and its degradation products with good resolution and measures the dynamic substance at minute fixation levels. The developed method was explicit, delicate. Consequently, the proposed technique can be adjusted to ordinary examination in pharmaceutical industry.

\section{Abbreviations}

ERT: Ertugliflozin; MET: Metformin; RT: Retention time; LOD: Limit of detection; LOQ: Limit of quantification; PPM: Parts per million; RSD: Relative standard deviation; PDA: Photo diode array; OPA: Orthophosphoric acid

\section{Acknowledgements}

This research would not have been possible without the support of Dr. Tulja Rani and my co authors Mounika and Ratna. I am so grateful to the assistance provided by Dr. Tulja Rani. Finally, it is with true pleasure that I acknowledge the contributions provided by my co-authors in the preparation of this manuscript.

\section{Authors' contributions}

S.B and G.T conducted the literature survey, designed the work, developed, and validated a new RP-HPLC method. M.M and M.R compiled, analyzed, and interpreted the data. S.B and G.T wrote the manuscript. All the authors read and approved the final manuscript.

Funding

No funding and self-financed. 
Availability of data and materials

All data and material are available upon request.

\section{Ethics approval and consent to participate}

Not applicable

\section{Consent for publication}

Not applicable

\section{Competing interests}

No competing interests to declare.

\section{Author details}

'Malla Reddy Institute of Pharmaceutical Sciences, Hyderabad, Telangana, India. ${ }^{2}$ Malla Reddy Pharmacy College, Hyderabad, Telangana, India.

Received: 21 May 2020 Accepted: 12 January 2021

Published online: 29 January 2021

\section{References}

1. FDA label: Merck \& Co.Inc. SEGLUROMETTM (Ertugliflozin and Metformin hydrochloride) tablets, for oral use. Initial US Approval,(2017): https://www Accessdata.fda.gov/drugsatfda_docs/label/2017209806s1b1.pdf.

2. Drug Profile for Ertugliflozin. Available from: https://www.drugbank.ca/ drugs/DB11827.

3. Cinti F, Moffa S, Impronta F, Cefalo CM, Sun VA, Sorice GP (2017) Spotlight on ertugliflozin and its potential in the treatment of type 2 diabetes. Drug Design, Development and Therapy 11:2905-2919. https://doi.org/10.2147/ DDDT.S114932

4. Drug Profile for Metformin. Available from: https:/www.drugbank.ca/drugs/ DB00331.

5. Wang YW, He SJ, Feng X, Cheng J, Luo YT, Tian L (2017) Metformin: a review of its potential indications. Drug Design Development Therap 11: 2421-2429. https://doi.org/10.2147/DDDT.S141675

6. Rena G, Hardie DG, Pearson ER (2017) The mechanisms of action of metformin. Diabetologia 60(9):1577-1585. https://doi.org/10.1007/s00125017-4342-z

7. Madiraju AK, Qiu Y, Perry RJ, Rahimi Y, Zhang XM, Zhang D (2018) Metformin inhibits gluconeogenesis via a redox dependent mechanism in vivo. Nature Medicine 24(9):1384-1394. https://doi.org/10.1038/s41591018-0125-4

8. Madiraju AK, Erion DM, Rahimi Y, Zhang XM, Braddock DT, Albright RA (2014) Metformin suppresses gluconeogenesis by inhibiting mitochondrial glycerophosphate dehydrogenase. Nat Med 510(7506):542-546. https://doi. org/10.1038/nature13270

9. FDA approves Segluromet.(2017) https://www.drugs.com/newdrugs/fdaapproves-segluromet-ertugliflozin-metformin hydrochloride-type-2-diabetes. Accessed 22 Dec 2017

10. Ertugliflozin/Metformin (By Mouth). Pubmed Health, 2018. https://www. ncbi,nml.nih.gov/pubmedhealth/PMHT0031142/.Accessesed Feb 2018

11. $\mathrm{ICH}$ harmonised tripartite guideline (2003) Stability testing of new drug substances and products, Q1A (R2). International Conference on Harmonization, pp 1-18

12. International Conference on Harmonisation of technical requirements for registration of pharmaceuticals for human use (2003) ICH Harmonised tripartite guideline. In: Stability testing of new drug substances and products Q1A (R2)

13. International Conference on Harmonisation of technical requirements for registration of pharmaceuticals for human use (1996) ICH Harmonised tripartite guideline. In: Stability testing: photostability testing of new drug substances and products Q1B

14. Harsha Hruditha P, Jayachandra Reddy P (2020) Development and validation of stability indicating HPLC method for simultaneous estimation of Metformin and Ertugliflozin. Int J Chem Pharm Sci 8(2):45-48

15. Jagadeesh K, Annapurna N (2019) Stability indicating method development and validation of metformin and ertugliflozin by high-performance liquid chromatography with PDA detection and its application to tablet dosage form. Asian J Pharm Clin Res 12(3):353-358

16. Wajahat S, Ahmed A, Khan G, Anas S, Absar A, Qureshi (2020) Analytical method development and validation for simultaneous estimation of ertugliflozin and metformin $\mathrm{HCl}$ in bulk and pharmaceutical dosage form by HPLC. Int J Pharm Sci Res 11(1):226-232

17. China Babu D, Madhusudhana C, Mastanamma SK (2019) A new stress indicating RP-HPLC method development and validation for the simultaneous estimation of ertugliflozin and metformin in bulk and its tablet dosage form. Indian drugs 56(2):39-46

18. Nizami T, Shrivastava B, Sharma P (2018) Analytical method development and validation for simultaneous estimation of Ertugliflozin and Metformin in tablet dosage form by RP-HPLC method. Int J Pharm Life Sci 9(7):5854-5859

19. ICH harmonized Triplicate guideline (2005): Validation of analytical procedures : text and methodology Q2 (R1).

\section{Publisher's Note}

Springer Nature remains neutral with regard to jurisdictional claims in published maps and institutional affiliations.

\section{Submit your manuscript to a SpringerOpen ${ }^{\circ}$ journal and benefit from:}

- Convenient online submission

- Rigorous peer review

- Open access: articles freely available online

- High visibility within the field

- Retaining the copyright to your article

Submit your next manuscript at $\boldsymbol{\nabla}$ springeropen.com 